\title{
Eros and Self-Realization: Zora Neale Hurston's Janie and Flora Nwapa's Efuru
}

\author{
F. FIONA MOOLLA \\ University of the Western Cape
}

ABSTRACT A comparative analysis of Zora Neale Hurston's Their Eyes Were Watching God and Flora Nwapa's Efuru suggests the importance of romantic love to the selfactualization of the heroines of these novels, whose authors share similar biographies, concerns, and literary positions in the spheres of African American and African literatures respectively. For Hurston, eros paradoxically represents the ultimately unfulfilled possibility for self-realization that finally may be achieved only in and through the self. By contrast, for Nwapa, the focus shifts from the centrality of romantic love to the complex and contradictory place of childbearing in female self-realization. However, finally, self-actualization is achieved with other women in identification with Mammywater, the powerful Igbo lake goddess.

KEYWORDS Their Eyes Were Watching God, Efuru, romantic love, female self-realization

I have a strong suspicion, but I can't be sure, that much that passes for love is a golded-up moment walking in its sleep. Some people know that it is the walk of the dead, but in desperation and desolation, they have staked everything on life after death and the resurrection, so they haunt the graveyard. They build an altar on the tomb and wait there like faithful Mary for the stone to roll away. So the moment has authority over all their lives. They pray constantly for the miracle of the moment to burst its bonds and spread out over time. -Zora Neale Hurston, Dust Tracks on a Road 


\section{Introduction}

Thus concludes the chapter titled "Love" in Zora Neale Hurston's autobiography, Dust Tracks on a Road. The passage captures the contradiction in the essay's reflections on life and love in its tone of personal romantic disillusionment, shot through nevertheless with the retrospective recognition that, despite being ephemeral, love, troublingly, lies at the heart of life. Romantic love, it would seem, is an emotion that fires the earliest recollections of the autobiographical subject; however, it is a fire that burns both passionately and destructively. Zora loves what she cannot possess and, by contrast, does not want to be possessed in love, which, finally, cannot take possession of her entire being for all time. She recalls starting to fall in love "before I was seven years old" (Dust Tracks 203), admiring from her garden gate the dapper young men, who do not deign to notice her childish self, walking by on the arms of their young lady beloveds. While the memories of Zora's marriage to her college sweetheart are suffused with the dank oppression of the tomb of convention and familiarity, it is the tempestuous elations of the relationship with "P.M.P." (205), Zora's junior in age but equal in strength of character, physical attractions and, most importantly, intelligence that make her "not just fall in love" but make a "parachute jump" into love (205). If the girl Zora could not possess the older men of her dreams, the older Zora does not stand to be possessed by the younger man of her desire, whose objective is to make domesticity, and the deity of his self, the center of her existence. Escaping the possessive patriarchies of the relationship that is at the heart of her life, Zora tries "to embalm all the tenderness of [her] passion for [P.M.P.] in Their Eyes Were Watching God" (211), the novel she writes in seven weeks on a research trip in Jamaica (Their Eyes 215), when a Guggenheim Fellowship allows her the financial freedom to break free of the love bond. In retrospect, the more mature, wiser Zora, whose fiercely autonomous streak has never abated, recognizes that eros is both a golden god and a zombie, whose moment in time is transitory and, if it endures at all, endures as a half-life without vitality. Love is a god that will not reign in glory through the rich life of which, finally, Zora, the goddess, must remain at the center. Paradoxically, collective folk wisdom captures Zora's individualist realization that there are less painful ways to be hurt than by the ambiguously, destructive, and beautiful thing that 
is love. The chapter closes with the folk rhyme: "Love is a funny thing; Love is a blossom; / If you want your finger bit, poke it at a possum" (214). Thus common wisdom, in a nutshell, declares that love has it charms, but love hurts; and there are simpler ways to be hurt if such are one's desires. However, the paradox remains that romantic love is deeply constitutive of Zora's complex life that moves from extreme highs to extreme lows.

Zora's closing autobiographical reflections on love, presented in the epigraph to this article, encapsulate the exploration of love in Hurston's Their Eyes Were Watching God in significant ways. This novel has achieved world literature "classic" status in the popular literary media along with Milan Kundera's The Unbearable Lightness of Being (1984), Aldous Huxley's Brave New World (1932) and Gabriel García Márquez's One Hundred Years of Solitude (1967), among other novels, as noted by Cheryl A. Wall, doyen of Hurston studies (Zora 3). In the context of African American literature, Hurston's accomplishments in American history, anthropology, politics, and aesthetics, are channeled specifically through the question of romantic love, as most notably recognized by feminist artist-activist June Jordan. Jordan's influential 1974 article in Black World magazine contrasts Hurston's achievement of "affirmation" with Richard Wright's politics of "protest." Hurston's personal background and general animus is compared with Wright's; in particular, the nurturing all-black environment of the Eatonville of Hurston's formative years is contrasted with the hostile white environments in which Wright came to consciousness of himself and his racially determined position in American society. Jordan's observations about Hurston's attainment are drawn centrally from her reading of Their Eyes Were Watching God:

You can see [Hurston's] immoveable, all-Black orientation in Their Eyes Were Watching God: whites do not figure in this story of Black love [sic]; white anything or anybody is not important. What matters is the Black woman and the Black man who come together in a believable, contagious, full Blacklove that makes you want to go and seek and find, likewise, soon as you finish the book. ... Unquestionably, Their Eyes Were Watching God is the prototypical Black novel of affirmation; it is the most successful, convincing and exemplary novel of Blacklove we have. Period. . . Consequently this novel centers itself on Blacklove-even as [Wright's] Native Son rivets itself upon white hatred. (Jordan 6-7) 
In this seminal article, Jordan thus positions Their Eyes Were Watching God as the prototypical novel in the African American literary tradition of racially inflected romantic love-it is the "exemplary novel of Blacklove."

Crossing the Atlantic in the reverse direction to the Atlantic crossing that informs Hurston's world, Flora Nwapa's Efuru (1966), the first novel by an African woman writer, also addresses romantic love: "One moonlit night, they went out. They talked of a number of things, their life and their happiness. Efuru told him that she would drown herself in the lake if he did not marry her. Adizua told her he loved her very much and that even the dust she trod on meant something to him (Efuru 7). Thus begins this Igbo-Anglophone Nigerian novel, written about three decades after Their Eyes Were Watching God. As with the protagonist Janie in Their Eyes Were Watching God, Nwapa's principal character, Efuru, breaks convention in pursuit of love in her journey toward self-fulfillment. Efuru, quite scandalously in her Igbo context, and independent of her father and family, selects as husband the man of her desire, negotiating her marriage and everything attendant on the marriage herself. Given the wellknown flexibility of Igbo culture, Efuru's father and family come around to accepting her choice and her actions, which in every way run counter to social norms. While romantic love is a volatile feature of village life everywhere, attested to in love songs across the world across all ages, for Efuru to have made love the basis of her autonomous choice in marriage is exceptional. In Efuru, Nwapa could be considered to have written a second novel of Blacklove but, as the terseness of the description and experience of love in the lines above suggest, romantic love in the context in which Nwapa writes is not in and of itself the central personal affirmation it is in Hurston's context.

That romantic love occupies a different position in the worlds of these two black women writers in different historical contexts on either shore of the Atlantic is what the analysis of their novels will further show. Both Hurston and Nwapa have written novels about love, but the nature of love and the significance of love are different in their dissimilar cultural settings. For Hurston, love seems to achieve its apogee in erotic unity, but union with the beloved is fleeting and, finally, fulfillment is acquired in and through the heroine herself. In the case of Nwapa's heroine Efuru, romantic love is intimately intertwined with childbearing, and the failure of both the love affair and procreation redirects self-fulfillment to 
relationships with other women in identification with Mammywater, the Oguta lake goddess, who is the protector of women.

There is much more, however, that makes this North Atlantic literary crossing interesting and revealing. There are also overwhelming similarities between the two novels that will be explored more carefully below. The commonalities between the backgrounds and positions of the two writers and their literary impact also demand consideration, as will be clear from the mapping of their respective social and literary contexts.

\section{Hurston and Nwapa: Tracing Parallel Biographies}

It was largely due to Alice Walker's rediscovery and "reinvention" of Hurston in the context of mid-1970s African American feminism that Zora Neale Hurston's work rose to the prominence it currently occupies. Walker, as is well known, almost literally "resurrected" Hurston from an unmarked grave, described in the 1975 quest narrative "Looking for Zora." This quest formed part of the establishment of a black female tradition of art and artists, whose essence is captured in the title of Walker's 1974 essay "In Search of Our Mother's Gardens." The tradition Walker uncovers includes the literary inheritances of Phyllis Wheatley, Lucy Terry, Frances Harper, and Nella Larsen among others (238) but, most importantly, it singles out Zora Neale Hurston, whose life and work repeatedly is returned to in Walker's collection, also titled In Search of Our Mother's Gardens. Cheryl Wall identifies Hurston not only as Walker's main "literary foremother" (Zora "Introduction" 4) but also as the inspiration of the generations of black women writers who follow: "Allusions to Hurston's art and life recur in texts by writers as varied as Maya Angelou, Toni Cade Bambara, bell hooks, Paule Marshall, Terry McMillan, Toni Morrison, Gloria Naylor, and Ntozake Shange" (5). Wall adds that Walker is only Hurston's "most noted legatee" (5). Walker's elaboration of the conception of "womanism," which, among other connotations, foregrounds the intersection of race and gender, is also significantly inflected by her reading, specifically, of Hurston's life and work. In the first of four definitions of "womanism," which acts as an epigraph to the collection In Search of Our Mothers' Gardens, Walker elucidates that the term comes "[f]rom womanish ... [a] black feminist or feminist of color," linking the concept also with "outrageous, audacious, courageous, or willful behavior." The second 
definition of the term highlights love, for other women, but also for men, both sexual and nonsexual. The third definition suggests a sheer zest for life through the love of "music," "dance," "the moon," "the spirit," "food and roundness," "the folk," and "herself." The final definition of womanism suggests that "[w] omanist is to feminist as purple is to lavender" (xixii). The foregrounding of an exuberant black female experience within a wider human experience encompassed in the term "womanism" captures the "zeitgeist" inherited from Hurston.

Flora Nwapa, by contrast with Hurston, has not yet had her legacy fully acknowledged, although a legacy undoubtedly exists. This legacy in part is created, as we shall see in the discussion below, from the complex (and problematic) significance accorded childbearing in relation to female self-fulfillment. Buchi Emecheta, whose novel The Joys of Motherhood (1979), directly alludes to Efuru, is more well known than Nwapa, and more often included in considerations of African feminism. But if one focuses on Nwapa, we see that Nwapa's influence has major impact and that her legacy may be tracked even further than the influence on Emecheta, as will be identified below.

With the publication of Efuru in 1966, Flora Nwapa (1931-1993) was the first African female writer to publish a novel in English, which also went on to establish her reputation internationally. However, recognizing the constraints on publication for herself as a "third world woman," Nwapa also became the first African woman to establish a publishing house, Tana Press Limited, in 1977 (Umeh 22). Like Hurston's early years in the all-black town of Eatonville, Nwapa came from a culturally affirming background, growing up in Oguta, Eastern Nigeria, where her schoolteacher parents were part of an Igbo elite. Unlike Hurston, Nwapa's life was relatively secure, allowing her to earn degrees from the universities of Ibadan in Nigeria, and thereafter the University of Edinburgh, without the financial stresses and anxieties suffered by Hurston, which ultimately led to her funeral being paid for by the small community in which she found herself at her death (Walker, "Looking for Zora" 117).

Additionally, Hurston's fascination with and enthusiasm for anthropology is reflected in her Nigerian counterpart's interest in exploring Igbo culture in her fiction, in particular, the mythologies and social practices associated with the goddess Uhamiri, also known as Mammywater or the Lake Goddess, the patron deity of Oguta Lake. It is reflected also 
in Nwapa's talent for capturing "the flavor of the Igbo idiom" in her work (Wilentz 8). Like Hurston, whose insider-outsider subject position informed her autoethnography of black folk culture of the American South, Nwapa similarly, as a member of a modernizing Christian Nigerian intelligentsia, "returns to" and reinvents Igbo culture, as anthropologist Sabine Jell-Bahlsen makes clear in her appraisal of Nwapa's idiosyncratic use specifically of the Mammywater figure (37).

In her two major novels, Efuru and Idu (1970), both of which foreground female characters obliged to negotiate women's personal fulfillment in the ambiguities and paradoxes of the multiple crossroads of rapidly transforming cultural contexts (Nnaemeka 104, 108, 110), Nwapa, like Hurston, comes to present a powerful feminist sensibility, which is conscious of the ways in which gender and race are mutually informing. Nwapa, in fact, uses Walker's concept of "womanism" to describe her work in an interview (Umeh 22) but, as we shall see in the analysis of Efuru, Nwapa's reference to the term in the context of her own work, may need some qualification.

In the same way that Hurston's literary and political project comes to be contrasted with that of Richard Wright, a male contemporary, Nwapa comes to be compared with Chinua Achebe, fellow Igbo-Anglophone writer and "father" of Nigerian letters, for her representation of the neglected female Igbo world in her novels where, by contrast, women, love, and marriage take center stage. Moreover, Hurston's position as literary foremother is paralleled by Nwapa, as Gay Wilentz observes, in relation to the allusion in the title of Buchi Emecheta's The Joys of Motherhood to the closing lines of Nwapa's novel, Efuru, where women's dedication to the goddess Mammywater is contemplated: "She had never experienced the joy of motherhood. Why then did women worship her?" (221). Wilentz stresses further that "Flora Nwapa's commitment to create literature from the oral heritage of her foremothers has placed her in a continuum in which she, too, is a foremother to a new generation of readers and writers" (8). Thus Nwapa's legacy extends much further than the familiar development of some of her themes in Emecheta's novel, but that legacy has not been clearly tracked.

Although the similarities in the positions of Hurston and Nwapa are striking, the differences are equally compelling. In Nwapa's linking of love and marriage with a specific exploration of the pressures around the 
question of childbearing, noticeably absent in Hurston, the outlines of the differences between Hurston's and Nwapa's conceptions of female selfactualization begin to emerge. (Critics have observed that the absence of mother figures may be the consequence of the early and traumatic loss of Hurston's own mother.) Nwapa, in this respect, is the literary foremother of not only Emecheta but also a generation of more contemporary Igbo-Anglophone writers like Chimamanda Ngozi Adichie, Onuora Nzekwu, Akachi Adimora-Ezeigbo, and Chika Unigwe, in whose writing the marriage-procreation, rather than marriage-eroticism plot often is disproportionately foregrounded. Marriage and fertility have been the focus more generally in the Anglophone Nigerian (rather than specifically Igbo) novel also; for example, in Lola Shoneyin's The Secret Lives of Baba Segi's Wives (2010) and Ayòbámi Adébáyò's Stay With Me (2017) (Moolla 301-2). Procreation failure emerges as a concern in the literature of the wider West African region also (Gomez and Ndow 2015).

\section{Romantic Love in Their Eyes Were Watching God and Efuru}

Both Their Eyes Were Watching God and Efuru are explorations of women's self-fulfillment, principally through romantic love leading to heterosexual marriage. In this respect, these novels may be contrasted with novels of female self-realization through the independent life outside of marriage, through formal education, through female homosociality or homosexuality. The concepts of self-realization, self-fulfillment, and self-actualization are used as approximate synonyms in most literature on personality formation and, in a feminist context, may be traced back to Second Wave feminism in an Anglo-American context (Wolosky 11). Janie's life in Their Eyes Were Watching God is a series of experiments with marriage where, in each marriage, a different foundation for marriage is trialed, but is rejected with the protagonist finally achieving self-knowledge in and through herself outside of marriage. Efuru's life is one where marriage is entered into independently, solely out of personal desire, defined more by emotion than eroticism, but which subsequently must engage a range of social expectations and norms, of which the need to bear a child is paramount. Romantic love is the foundation of the most important marriages in the lives of each of the characters and plays a role in the self-realization of both heroines, but is more significant in Hurston's novel. 
Janie Crawford is pressured into marriage as a consequence of the sexual awakening against which her grandmother wishes to protect her. The passages describing sexuality are some of the most lyrical and most widely quoted in the scholarship of Their Eyes Were Watching God, but the crucial lines need to be cited again here:

She was stretched on her back beneath the pear tree soaking in the alto chant of the visiting bees, the gold of the sun and the panting breath of the breeze when the inaudible voice of it all came to her. She saw a dust-bearing bee sink into the sanctum of a bloom; the thousand sister-calyxes arch to meet the love embrace and the ecstatic shiver of the tree from root to tiniest branch creaming in every blossom and frothing with delight. So this was a marriage! She had been summoned to behold a revelation. Then Janie felt a pain remorseless sweet that left her limp and languid. (11)

Janie's failed attempt to fully embody this "golded" moment (to use the term from Hurston's autobiography), reflected here in the gold of the sun, and make it last a lifetime, is captured proleptically by the ultimate "pain" of the effort. It is the predominance of the erotic that has led most criticism of the novel to foreground sexuality as occupying its center.

This trend is succinctly summed up by Carla Kaplan, who suggests that Janie's quest for self-knowledge takes the form of the "story of a woman in search of an orgasm" (137). In the racialized social context of the early twentieth-century United States in which Hurston writes, bringing black female sexuality to light is a decidedly political act, as Kaplan also underscores alluding to the work of Hazel Carby. Carby suggests that it is because "racist sexual ideologies ... proclaimed the black woman to be a rampant sexual being, [that] in response black women writers either focused on defending their morality or displaced [their] sexuality onto another terrain" (Carby qtd. in Kaplan 144). The often unduly conservative response to the vilification of black female sexuality is not only evident in the work of black women writers but it also permeated the intellectual life and social movements of the period in which Hurston writes. The suppression of attention to black female sexuality is evident by its absence in the work, for example, of E. Franklin Frazier, influential sociologist of black family life in the United States in the first part of the twentieth century. 
The elision of black female sexuality is paradoxically caused further by the constrained conservatism of the ways in which black women's uplift movements responded to dominant Victorian stereotypes of white woman as "angel in the home," and the recalcitrant challenges to these stereotypes by white feminism, which promoted an opposing independence and sexual libertarianism as female ideals. Lovalerie King observes how the Black Women's Club Movement of the late nineteenth century, whose effects were still felt in the early twentieth century, "took as a primary mission in their uplift project the task of creating employment opportunities for black women that would allow them to avoid work situations where their sexual virtue could be easily compromised or undermined" (25). In writing back to this dominant literary and social discourse, which is constrained to deny black female sexuality, Hurston comes to place eroticism at the center of Janie Crawford's self-knowledge, leading finally to self-realization. It is important to note by contrast, however, that black female sexuality nevertheless was expressed in the liminal figure of the jazz blueswoman as Hazel Carby makes clear. Carby argues that the "Classic Blues" of the twenties and early thirties "is a discourse that articulates a cultural and political struggle over sexual relations: a struggle that is directed against the objectification of female sexuality within a patriarchal order but which also tries to reclaim women's bodies as the sexual and sensuous subjects of women's song" (474). Hurston's representation of black female sexuality thus goes against the grain of the literature of the period in which she writes, but not against some elements of popular culture.

Erotic self-discovery leads the young Janie to an awakening that colors her world and the people in it. Johnny Taylor, whom in her "former blindness" she saw as "shiftless," is new-gilded when the "golden dust of pollen . . beglamor[s] his rags and her eyes" (Their Eyes 11-12). When Janie's grandmother, Nanny, sees through the window her granddaughter "lacerated" by Johnny's kiss, an instinctive protective instinct takes over that precipitates Janie into her first marriage with Logan Killicks. For the grandmother, sex, rather than marriage, is linked not with self-realization but with procreation, which, in the context of plantation slavery, signifies eventual loss of the child who is the product of sex with the slave master, as his property. Sex, in the context of the slavery of the American South, leads also (as experienced by Nanny) to the cruel retribution, fuelled by 
complex jealousy, of the slave mistress who loses her hierarchical privilege through the husband's act that brings possession into play with desire. The grandmother had been raped and impregnated by her white slave master, indexing the violence of inter-racial patriarchy in the racialized slavery of the American South; and her mulatto daughter, Leafy, the product of the violation, is raped and impregnated by her black teacher, indexing the parallel violence of intraracial patriarchy, even within the upwardly mobile black middle class. Janie is the product of the second rape and impregnation.

Sexuality is not foregrounded in Nwapa's fictional universe at all, with the pleasures of eroticism ignored entirely in the novel. One reason for this may be that a discursive context that presents demeaning stereotypes of black female sexuality does not exist in Nwapa's world and, therefore, does need not be challenged. A conception of love, as suggested in the above extract from the beginning of Efuru, does exist, and what makes Efuru noteworthy is the fact that she, unlike the other members of her community, makes love the basis of her free and independent choice in marriage. Although the novel does not go into much detail regarding the reasons why Efuru falls in love with Adizua, requited love exists as an idyll in the early phase of the marriage. Thereafter and almost fatefully, however, Adizua begins to act erratically-the text suggests this behavior prevails since he is the wayward son of a wayward father. But Efuru's love holds true and is voiced again and again in the narrative, even in a song she sings to her husband when he becomes irrationally jealous on an occasion where she returns home late: "My dear husband, my love is true. / My dear husband, my love is constant" (30). Love, that emotion that allows one to feel completed in the beloved, that makes one believe one cannot exist without the beloved, and that makes one willing to sacrifice one's life for the beloved, is foregrounded in Efuru's relationship with her husband throughout the novel. The narrative is curiously noncommittal in its tone regarding Efuru's devotion. However, it is clear from the censure of Adizua's conduct by Efuru's mother-in-law, as well as by the wider community, that a Penelope-like loyalty is not expected of her. Efuru overlooks Adizua's errant ways because of her love for him, not because of societal pressure. A noticeable difference between the love of Efuru for Adizua and Janie for Tea Cake is that the erotic as a dimension of love is not presented as a privileged path to self-discovery and self-fulfillment in 
Nwapa's novel. Instead, self-realization is linked in complex and contradictory ways with childbearing; and problems with procreation are indirectly connected with failed romance.

The violence of rape leading to impregnation in Their Eyes Were Watching God captures the position of black women victimized by the collusions of white patriarchy in racialized slavery and its psychological intensification of the violence of black patriarchy. Even though slavery is a feature of the world Nwapa fictionalizes, the fact that it is not the chattel slavery shaping the personal and social histories of the characters in Their Eyes Were Watching God means that rape is not a symbolic problem endemic to the social order, and that children are a source of unconflicted happiness and wealth. Children are central to the perpetuation of the spiritual line running through parents to the ancestors in Efuru. The active and violent suppression of African traditional religious practices in favor of Christianity in the American South meant that the significance of children in the continuity of life across human and spirit worlds was to some extent lost. However, West Africa and the American South are similar and connected in other ways. Taiwo Adetunji Osinubi observes regarding literary representations of West African slavery and its connection with Atlantic slavery that:

For West African authors writing during the transition from colonization to national independence, representing slavery was an enterprise fraught with multiple contradictions. Slavery existed in West Africa in different forms and was embedded in different trajectories of abolition and memorialization. Writers had to heed the heterogeneity of slavery in its multiple temporalities. There was no single constellation for unifying the diverse memories and practices of slavery, which were dispersed in multiple circuits by the effects of colonial modernity. Although it is often named in the singular, slavery consisted of a meta-system of subordinations. (Osinubi 1-2)

Efuru is the daughter of a member of the indigenous elite that benefited from the Atlantic slave trade. The cannons boom on the death of her father, Nwashike Ogene, to announce "the departure of a great son, the last of the generation that had direct contact with the white people 
who exchanged their cannons, hot drinks and cheap ornaments for black slaves" (Nwapa 203). Nwashike thus is one node in a metasystem of subordinations, where he is a subordinate in European slavery but, at the same time, as patriarch, Osinubi suggests that he is complicit in the bondage of women like his daughter Efuru, who, metaphorically speaking, is a slave of patriarchy.

However, in other respects, Efuru is not property in the ways that American plantation slavery made women, men, and the children they bore property. Efuru breaks tradition by marrying for love, but she faithfully continues tradition in insisting that her bridewealth be paid to her father. (Bridewealth in the Igbo context is a form of security for the woman in the event of the breakdown of the marriage, where it supports the woman on her return to the paternal household.) Ironically, Efuru's bridewealth is not paid by her husband or his family, as it customarily should be, but by herself since, as a savvy and successful trader, she is an economically independent woman. Efuru thus pays her dowry herself, constituting security for the cost of her maintenance when she returns to her father's household after Adizua, the love of her life, abandons her for another woman. Efuru thus, unlike Janie who enjoys only a vicarious economic independence through the wealth she inherits as a widow, has her own property and is not herself symbolic property. Furthermore, as interpreted by Osinubi, Efuru is a "slaveowner" since she holds Ogea, the daughter of a struggling family, in debt bondage (5). She pays Ogea's father's debts in exchange for the service of the girl. Later she is keen to marry Ogea to her second husband to settle the marital tensions that exist in the polygynous household. Nwapa's presentation of slavery, especially the woman as slaveowner, may be contrasted with Buchi Emecheta's representations of slavery in The Slave Girl (1977) and The Joys of Motherhood (1979). In these novels, which implicitly and explicitly engage Efuru, patriarchal oppression through various narrative strategies is presented as a form of gendered slavery. Nwapa's and Emecheta's engagement of slavery foregrounds the modal differences between African and Western paradigms of slavery, operating coevally, without neglecting the personal impacts of either model.

Also unlike Janie, whose relationships with men-especially her second and third husbands - are marked by the jealousy of both spouses, Efuru's anxieties stem not from rivalries in love but from the fact that 
Adizua does not follow conventional paths in establishing polygynous relationships in a plural marriage, which is an accepted social practice, in fact, a norm encouraged by first wives themselves. (Polygyny is not alluded to at all in Their Eyes Were Watching God, and the bigamy of her second marriage, where Janie simply walks away from Logan Killicks with Joe Starks is not brought into explicit focus in the narrative.)

Influenced by Nanny's experience of plantation slavery, where enjoying property, rather than being enjoyed as property, comes to dominate the conception of female self-actualization, Janie's first two marriages are marriages in which material concerns dominate. Tiffany Patterson distinguishes the two marriages as allowing the exploration of the implications for women of two different property regimes in the context of racialized American economic history: The marriage to Logan Killicks brings the significance of land to the fore, which represents "the cornerstone of freedom in the Reconstruction South." But since Killicks "has no 'political' manhood because he has no political rights ... in the Jim Crow South," he is not in a position to protect either his land or his wife (Patterson 118). Thus the possibility for personal advancement of the wife through marriage to "landed" property is stymied.

The marriage to Jody "Joe" Starks, by contrast, explores the advancement possibilities of business as a mode of black entry into the middle class. Patterson suggests that the town of which Jody Starks is mayor, "epitomizes the entrepreneurial solution of Booker T. Washington's era and reveals the class and color hierarchies that were then emerging in African American life" (119). In Janie's second marriage, Starks acts as proxy for her material progress, which ought to bring self-fulfillment through uplift from poverty. However, both of these avenues are presented as trajectories that ultimately fail Janie. Killicks, contrary to Nanny's hopes of a life of ease for Janie, confirms her granddaughter's fate as a black woman by turning her into "de mule uh de world" (Their Eyes 14). Starks enacts a black patriarchy of possession through his psychological control and abuse of his "trophy" mulatto wife that sees her made the "spit cup" of his sarcasm and insults (20).

With the marriage to Tea Cake, avenues to female self-realization through the property aspirations of the husband are implicitly disavowed in the simple, organic existence of the husband and wife "[d]own in the everglades there, down on the muck" (Their Eyes 7). As expressed by 
Constante González Groba, quoted by Inés Casas Maroto, "the physical and social descent of Janie to the farming area of 'the muck' is ultimately an ascent to higher and more authentic layers of being" (Maroto 78). The life of the couple in the everglades is presented as a pastoral idyll, which is threatened only by the fateful and inescapable reassertion of the violence of masculine proprietorial desire to possess the woman, exacerbated by the complicated racial politics of post-reconstruction America. Tea Cake responds defensively, and sadistically, to the attempts of the meddling Mrs. Turner, who had built "an altar" to unattainable Caucasian characteristics (Their Eyes 145), to hitch up her social, racial and economically "superior" brother with Janie:

When Mrs Turner's brother came and she brought him over to be introduced, Tea Cake had a brainstorm. Before the week was over, he had whipped Janie. Not because her behavior justified his jealousy, but it relieved that awful fear inside him. Being able to whip her reassured in possession. No brutal beating at all. He just slapped her around a bit to show he was boss. (147)

Male violence against women comes in the end to be symbolized by Tea Cake's rabies, a word that etymologically suggests both the contagious disease and mad violence, or fury, in response to which Janie's killing of Tea Cake becomes justified.

By contrast with Janie and Tea Cake's love-idyll brought to an end by the violence of the hurricane that precipitates the violence of Janie shooting Tea Cake, the love-idyll enjoyed by Efuru and Adizua is threatened by the couple's inability to conceive a child. Their childlessness affects Efuru more than it does Adizua, with Efuru declaring, "surely God cannot deny me the joy of motherhood" (24). Eventually, after a visit to a dibia, or spiritual healer, Efuru becomes pregnant and gives birth to a daughter. Unfortunately, the child dies of an illness, and Efuru buries her alone, since Adizua, it is rumored, has taken up with a married woman. Efuru then contracts a second marriage to Gilbert, a childhood friend, based this time purely on utilitarian concerns rather than romantic love, and with the approval of her family, following all the conventional and ritual obligations. But again procreation failure unsettles the relationship, with Efuru encouraging the husband to take a second wife in order that a child 
be born into the family. After a series of disappointments with Gilbertin particular, his absence at her father's funeral-Efuru returns to her father's household for a second time.

Thus, while childbearing is the final consummation of romantic love in Efuru, erotic fulfillment lies at the heart of the romantic relationship in Their Eyes Were Watching God. In both novels, the specific ways in which male partners negotiate love lead to tensions that result in the dissolution of the ties that bind the couples. As far as the link between love and procreation is concerned, it is fascinating that fecundity dominates the imagery used to represent the erotic in Their Eyes Were Watching God. Janie's burgeoning sexuality is allegorized through the potential fruitfulness of the pear tree, the shape of whose fruit suggests the swelling of pregnancy. Her sexual epiphany occurs in the life-giving season of springtime. The sexual act, furthermore, is captured through a description of pollination that is ritualized and sensualized. Despite erotic descriptions that are pregnant with the possibility of life, Their Eyes Were Watching God remains curiously bereft of children, as observed by Michael Awkward and Michelle Johnson:

[G]iven the centrality of the image of pollination to the novel, both in the much-discussed backyard scene, in which Janie experiences nature orgasmically, and in her "love thoughts" about Tea Cake, whom she believed could be the bee to her blossom, Janie's childlessness is a subject that scholars might profitably explore. Indeed, one issue that has barely been discussed in examinations of Hurston's fictive renderings of Eatonville is its strange absence of children. (Awkward 134)

The fecundity of Their Eyes Were Watching God thus is contrasted with the infertility and bareness of Efuru, where Efuru finally finds her self-fulfillment through devotion to the goddess Mammywater. It becomes clear at the end of the narrative that Efuru's childlessness, but great success in trade, is a consequence of being chosen as an acolyte of the Lake Goddess. Like the Lake Goddess, Efuru has an otherworldly beauty offset by her luxuriant beautiful long hair: "Efuru slept soundly that night. She dreamt of the woman of the lake, her beauty, her long hair and her riches. She was happy, she was wealthy. She was beautiful. She gave women beauty and 
wealth but she had no child. She has never experienced the joy of motherhood. Why then did women worship her?" (Efuru 221). Self-realization for Efuru thus is achieved through the collective horizon represented by the goddess, the way out for women in a society where childbearing is an essential part of individual and social fulfillment, but where beauty and wealth are socially admired.

Janie, by contrast, is not the worshipper of a goddess, but is a goddess herself. Daphne Lamothe observes that "Hurston infuses Janie with the characteristics of two aspects of [the goddess Ezili]: Ezili Freda, the mulatta goddess of love, and Ezili Danto, the black goddess who is associated with maternal rage" (164). Lamothe proceeds to detail the numerous correspondences between the cultural representation of these two spirits and the characterization of Janie through vodou connotations embedded in language and imagery. Despite the similarities between Janie and the voudou goddesses, it is Janie's characterization as goddess unto herself that represents her final bittersweet self-realization. William Ramsey, quoting Dianne Sadoff sums up the double-bind from which Janie ultimately escapes as follows: "For Janie, Tea Cake is undeniably attractive and liberating, but beneath her love lurks a troubling unease. . . Neither anger alone nor love alone is Hurston's narrating motive. The anger is there, covertly, Sadoff perceptively states, as 'the subterranean theme in Hurston's Eyes that women most truly become themselves without men.' . . . But the love equally is there, the recognition that in Tea Cake's loss that to privilege personal autonomy over heterosexual love is to suffer a stinging sacrifice" (Ramsey 60). However, as an analysis of the closing paragraph of Their Eyes Were Watching God makes clear, the love for Tea Cake is a sacrifice Janie is compelled to make. Thinking back to the trauma of her trial for shooting Tea Cake, captured in "a sobbing sigh" of exhaustion and grief that enters everything in the courtroom, Janie remembers:

Then Tea Cake came prancing around her where she was and the song of the sigh flew out of the window and lit in the top of the pine trees. Tea Cake, with the sun for a shawl. Of course he wasn't dead. He could never be dead until she herself had finished feeling and thinking. The kiss of his memory made pictures of love and light against the wall. Here was peace. She pulled in her horizon 
like a great fish-net. Pulled it from around the waist of the world and draped it over her shoulder. So much of life in its meshes! She called in her soul to come and see. (193)

The love for Tea Cake that endures is the love that is channeled through Janie's consciousness. The Tea Cake who finally fulfills Janie is the lover that she self-reflexively constructs both through affect and intellect: "He could never be dead until she herself had finished feeling and thinking." Thus the autonomy-rupturing unity with the other desired in the rapture of love may be achieved only once Tea Cake has died and lives on in Janie's memory. Janie's horizon of self-fulfillment, furthermore, is her own: she pulls in "her horizon" like a fish net. This may be contrasted with Efuru's horizon which is a horizon shared with other Mammywater worshippers, of which the Lake Goddess and her mythology and rituals are at the center.

\section{Conclusion}

Thus we see that love plays a role in the self-realization of the characters on either shore of the Atlantic, but the essence of love is different in each case. For Efuru, it is procreation that seals love; for Janie it is eroticism. In both cases, however, through the failings of the men they love, these women finally find self-actualization outside of the love relationship: Efuru through the shared practices of the worship of the goddess Mammywater, who provides the social alternative for women who cannot bear children; for Janie through the goddess of her autonomous self. In this respect, Walker's concept of womanism, which is significantly shaped out of Walker's reading of Hurston-and with which Nwapa identifiesneeds to be qualified. Womanism links gender with race, but blackness does not explain the very different conceptions of self-realization within different epistemological paradigms, embodied in the characters of Janie and Efuru. Here we see that culture and historical context shape figurings of female self-fulfillment. Nwapa, as noted above, identifies with the concept of womanism whose central precepts Walker largely draws from her reading of Hurston. However, womanism for Nwapa may point at a somewhat different intersectionality to the intersectionality of gender and race. Womanism in Nwapa's context seems to point at an intersectionality 
that connects with other women in their apprehension of self-realization through the consolations embodied in Mammywater, signaling an epistemological difference that cannot be elided by shared blackness.

F. Fiona Moolla is a lecturer in the English Department at the University of the Western Cape, South Africa. She specializes in the African novel, but has a general interest in postcolonial, comparative, and world literature. She is the author of Reading Nuruddin Farah: The Individual, the Novel \& the Idea of Home (James Currey, 2014), and is the editor of Natures of Africa: Ecocriticism and Animal Studies in Contemporary Cultural Forms (Wits UP, 2016). Her current research interest considers romantic love in African literatures and oratures.

\section{WORKS CITED}

Adébáyò, Ayòbámi. Stay With Me. Canongate, 2017.

Adichie, Chimamanda Ngozi. Half of a Yellow Sun. Harper Perennial, 2007.

Awkward, Michael, and Michelle Johnson. "Zora Neale Hurston." Zora Neale Hurston, edited by Harold Bloom, pp. 131-42.

Bloom, Harold, editor. Zora Neale Hurston. Infobase Publishing, 2008.

Carby, Hazel. "It Jus Be's Dat Way Sometime: The Sexual Politics of Women's Blues."

The Jazz Cadence of American Culture, edited by Robert G. O'Meally. Columbia University Press, 1998, pp. 470-83.

Emecheta, Buchi. The Joys of Motherhood. Heinemann, 1979.

Gomez, Pierre, and Isatou Ndow. Gendered Voices from the Gambia: A Gendered Perspective in Selected Gambian Books. Global Hands Publishing, 2015.

Hurston, Zora Neale. Dust Tracks on a Road. Harper Perennial, 2006.

- Their Eyes Were Watching God. Harper Perennial, 2006.

Jell-Bahlsen, Sabine. "The Concept of Mammywater in Flora Nwapa's Novels." Research in African Literatures, vol. 26, no. 2, 1995, pp. 30-41. JSTOR, 27 Aug. 2017.

Jordan, June. "On Richard Wright and Zora Neale Hurston." Black World 23, August 1974, pp. 4-8.

Kaplan, Carla. "The Erotics of Talk: 'That Oldest Human Longing' in Their Eyes Were Watching God." Zora Neale Hurston's Their Eyes Were Watching God: A Casebook, edited by Cheryl A. Wall, Oxford UP, 2000.

King, Lovalerie. The Cambridge Introduction to Zora Neale Hurston. Cambridge UP, 2008.

Lamothe, Daphne. "Voudou Imagery, African-American Tradition and Cultural

Transformation in Zora Neale Hurston's Their Eyes Were Watching God." Zora Neale Hurston, edited by Harold Bloom, pp. 159-80.

Maroto, Inés Casas. "So this was a marriage!': Intersections of Natural Imagery and the Semiotics of Space in Zora Neale Hurston's Their Eyes Were Watching God." Journal of English Studies, vol. 11, 2013, pp. 69-82. EBSCOhost, 23 Jan. 2018.

Moolla, F. Fiona. "'Foundational Fictions': Variations of the Marriage Plot in Flora Nwapa's Early Anglophone-Igbo Novels." Routledge Handbook of African Literature, edited by Moradewun Adejunmobi and Carli Coetzee, Routledge, 2019, pp. 290-304. 
Nnaemeka, Obioma. "Feminism, Rebellious Women, and Cultural Boundaries: Rereading Flora Nwapa and Her Compatriots." Research in African Literatures, vol. 26, no. 2, 1995, pp. 80-113. JSTOR, 27 Aug 2017.

Nwapa, Flora. Efuru. Heinemann, 1966.

- Idu. Heinemann, 1970.

Osinubi, Taiwo Adetunji. "Provincializing Slavery: Atlantic Economies in Flora Nwapa's Efuru." Research in African Literatures, vol. 45, no. 3, 2014, pp, 1-26.

Patterson, Tiffany Ruby. Zora Neale Hurston and a History of Southern Life. Temple UP, 2005.

Ramsey, William M. “The Compelling Ambivalence of Zora Neale Hurston's Their Eyes Were Watching God." Zora Neale Hurston, edited by Harold Bloom, pp. 51-64.

Shoneyin, Lola. The Secret Lives of Baba Segi's Wives. Serpent's Tail, 2010.

Tate, Claudia. "Hitting 'A Straight Lick with a Crooked Stick': Seraph on the Suwanee, Zora Neale Hurston's Whiteface Novel." Zora Neale Hurston, edited by Harold Bloom, pp. 143-58.

Umeh, Marie. "The Poetics of Economic Independence for Female Empowerment: An Interview with Flora Nwapa." Research in African Literatures, vol. 26, no. 2, 1995 , pp. 22-29. JSTOR, 27 Aug. 2017.

Walker, Alice. In Search of Our Mothers' Gardens: Womanist Prose. Harcourt, 1983.

— . "Looking for Zora." In Search of Our Mothers' Gardens: Womanist Prose. Harcourt, 1983, pp. 93-118.

Wall, Cheryl A., editor. Zora Neale Hurston's Their Eyes Were Watching God: A Casebook. Oxford UP, 2000.

Wilentz, Gay. "Flora Nwapa, 1931-1993." The Women's Review of Books, vol. 11, no. 6, 1994, p. 8. JSTOR, 27 Aug. 2017.

Wolosky, Shira. Feminist Theory Across Disciplines. Routledge, 2013. 